VOX PATRUM $32(2012)$ t. 57

Anna Z. ZMORZANKA

(Lublin, KUL)

\title{
„PLATOŃSKI” MARSANES I JEGO PITAGOREJSKI WĄTEK
}

Marsanes (NHC X 1, 10 - 68, 18) ${ }^{1}$ należy do jednych z ciekawszych utworów z kolekcji z Nag Hammadi ${ }^{2}$. To - powstałe najprawdopodobniej w III wieku w Aleksandrii ${ }^{3}$ i zaliczane do gnozy setiańskiej ${ }^{4}$ (ale niestety niekompletne)

\footnotetext{
${ }^{1} \mathrm{~W}$ artykule posługuję się wydaniem: Marsanes, NHC X 1, 1, 10-68*, 18, ed. B.A. Pearson, w: Nag Hammadi Codices IX and X, NHS 15, Leiden 1981, 229-250 (= The Coptic Gnostic Library: a complete edition of the Nag Hammadi Codices, general editor J.M. Robinson, vol. 5, Leiden 2000, 252-346).

${ }^{2}$ Publikacje na temat Marsanesa odnotowuje D.M. Scholera w II i III tomie bibliografii poświęconej tekstom z Nag Hammadi, zob. tenże, Nag Hammadi Bibliography 1970-1994, Nag Hammadi Studies 32, Leiden 1997, 441-442; tenże, Nag Hammadi Bibliography: 1995-2006, Nag Hammadi and Manichean Studies 65, Leiden 2009, 234-235. Na temat Marsanesa piszą: B.A. Pearson, The tractate Marsanes (NHC X) and the Platonic tradition, w: Festschrift für Hans Jonas, ed. B. Aland, Göttingen 1978, 373-384; tenże, Introduction, w: Nag Hammadi Codices IX and X, ed. B.A. Pearson, NHS 15, Leiden 1981, 229-250 (= The Coptic Gnostic Library, vol. 5, s. 229-250); tenże, The figure of Seth in Gnostic literature, w: The Rediscovery of Gnosticism, vol. 2: Sethian Gnosticism, ed. B. Layton, Supplements to Numen 41, Leiden 1981, 472-504; G.A. Wewers, Das Wort „Gott” als Problem der religiösen Sprache, „Kairos“ 24 (1982) 207-219; B.A. Pearson, Gnosticism as Platonism: with special reference to Marsanes (NHC 10, 1), HTR 77 (1984) 55-72 (dalej cyt: Gnosticism as Platonism (I); M.L. Peel, Marsanes, w: Mercer Dictionary of the Bible, ed. W.E. Mills et al., Macon 1990, 554-555; M.W. Meyer, Marsanes, w: The Coptic Encyclopedia, ed. A.S. Atiya, vol. 8, New York 1991, 1547; B.A. Pearson, Gnosticism as Platonism, w: B.A. Pearson, Gnosticism, Judaism, and Egyptian Christianity, Studies in Antiquity and Christianity, Mineapolis 1990, 148164; B.A. Pearson, Marsanes (NHC X,1), w: The Anchor Bible Dictionary, vol. 4, New York 1992, 572-573; tenże, Theurgic tendencies in Gnosticism and Iamblichus's conception of theurgy, w: Neoplatonism and Gnosticism, ed. R.T. Wallis, Albany 1992, 253-276; J.F. Finamore, Iamblichus, the Sethian, and Marsanes, w: Gnosticism and later Platonism, ed. J.D. Turner - R. Majercik, Atlanta 2000, 225-257; J.D. Turner, Introduction, w: Marsanès, ed. W.P. Funk - P.H. Poirier - J.D. Turner, Bibliothèque Copte de Nag Hammadi. Section «Textes» 27, Québec 2000, 1-248; tenże, Sethian Gnosticism and the Platonic tradition, Bibliothèque Copte de Nag Hammadi. Section «Études»6, Québec 2001, passim; J. Brankaer, Marsanes: un texte Séthien Platonisant?, „Le Muséon” 118 (2005) 21-41; R. van den Broek, Gnostic religion in Antiquity, Cambridge 2013, 71-90.

${ }^{3}$ Por. Turner, Introduction, s. 1. Pismo zachowało się w przekładzie na język koptyjski (dialekt subachimski); na temat języka tego utworu zob. Pearson, Introduction, s. 223-227.

${ }^{4}$ H.M. Schenke do gnozy setiańskiej zaliczył 11 utworów: Apokryf Jana (NHC II 1; III 1; IV 1; BG 2), Hipostaza Archontów (NHC II 4), Ewangelia Egipcjan (NHC III 2; IV 2), Apokalipsa Adama
} 
pismo - stanowi rodzaj profetycznej wypowiedzi ${ }^{5}$, pochodzącej od tytułowego Marsanesa $^{6}$, którego imię ([M]A PCaNHC) znajdujemy w ostatnim wersie ${ }^{7}$. Pierwszy redaktor i badacz utworu, B.A. Pearson, zaliczył go do pism platońskich, do których (jego zdaniem) należą też Allogens, Trzy Stele Seta i Zostrianos; według niego, oddziaływanie tej filozofii (ze szczególnym wskazaniem na rolę średniego platonizmu) widać zwłaszcza w przyjętej przez autorów terminologii implikującej określoną wizję rzeczywistości, co widoczne jest zwłaszcza w Marsanesie ${ }^{8}$. Pogląd o wpływie platonizmu podziela inny z badaczy, J.D. Turner (a wymienione wyżej tytuły określa mianem „Platonizing Sethian treatises"10) oraz m.in. E.M. Yamauchi, który uważa, iż na wspomniana grupę utworów wpływ wywarły wszystkie stadia filozofii platońskiej (a więc: platonizm, średni platonizm i neoplatonizm) a także stoicyzm i pitagoreizm ${ }^{11}$.

(NHC V 5), Trzy Stele Seta (NHC VII 5), Zostrianos (NHC VIII 1), Melchizedek (NHC IX 1), Pieśn o Norei (NHC IX 2), Marsanes (NHC X 1), Potrójna Protenoia (NHC XIII 1) oraz Pismo bez tytutu z Kodeksu Brutianus (podaję za: Pearson, Theurgic tendencies in Gnosticism, s. 270, nota 21); do tej grupy zaliczany jest też przez niektórych uczonych (B.A. Pearson, J. Turner) Allogenes (NHC X,1). J.D. Turner uważa, iż Marsanes (podobnie jak Pismo bez tytułu) stanowi prawdopodobnie jedno z ostatnich pism tej szkoły, jakie posiadamy (zob. tenże, Sethian Gnosticism, s. 189). Wśród charakterystycznych cech tej grupy utworów B.A. Pearson wymienia trzy elementy: (1) figure/postać Seta, syna Adama, boskiego zbawcy, który wciela się w różnych proroków, i którego duchowe zejście konstytuuje wybranych; (2) podstawową triadę: Ojca, Matkę (Barbelo) i Syna; (3) czterech oświeconych, por. Gnosticism as Platonism (I), s. 59.

${ }^{5}$ Por. Turner, Introduction, s. 23; według B.A. Pearsona (Introduction, s. 233-234), utwór ten stanowi rodzaj apokalipsy..

${ }^{6}$ Według B.A. Pearsona (Introduction, s. 230-233), jest to autor fikcyjny. Do takich wniosków dochodzi w konkluzji dłuższych wywodów, w których wykazuje zarazem, iż istniał jakiś gnostycki nauczyciel lub prorok o tym (wywodzącym się z języka syryjskiego, według C. Elsasa) imieniu. Albowiem pojawia się ono w dosłownej lub zbliżonej wersji w literaturze i to w kontekście gnostyckim. W brzmieniu dosłownym występuje w piśmie bez tytułu z Kodeksu Brutianus, gdzie (obok Nikoteusa) jest wielkim i doskonałym mężem, który dostąpił poznania, spraw wymagających ,języka światła". Z kolei Epifaniusz (Panarion 40, 7,6) stwierdza, iż w sekcie archontyków znajdował się niejaki Marcjades lub Marcjanos, Porfiriusz zaś pisze (Vita Plotini 16), iż wśród gnostyków istnieli różni profeci, jednak nie podaje imienia Marsanesa; zob. też Turner Introduction, s. 2-4; tenże, Sethian Gnosticism, s. 189.

${ }^{7}$ Por. Marsanes, NHC X 68,18, w: The Coptic Gnostic Library, vol. 5, s. 346; zob. też Pearson, Introduction, s. 230.

${ }^{8}$ Por. Pearson, Introduction, s. 244-248; tenże, Gnosticism as Platonism (I), s. 56-57.

${ }^{9}$ Por. J.D. Turner, Revelation as the path of ignorance. The Sethian Platonizing Apocalypse «Allogenes», w: Revelation, literature and community in Late Antiquity, ed. P. Townsend - M. Vidas, Tübingen 2011, 103-115, spec. s. 103-108 („The Platonizing Sethian Treatises”).

${ }^{10}$ Por. Turner, Sethian Gnosticism, s. 52-54; tenże, The Gnostic Sethians and Middle Platonism: Interpretations of the „Timaeus” and „Parmenides”, VigCh 60 (2006) 9-64. Określenie „Platonizing Sethian treatises" zostało powszechnie przyjęte w literaturze przedmiotu, zob. R. Cox, By the same word: creation and salvation in Hellenistic Judaism and Early Christianity, Berlin 2007, 317-317.

${ }^{11}$ Por. E.M. Yamauchi, Jewish Gnosticism?, w: Studies in Gnosticism and Helenistic religions: presented to Gilles Quispel, ed. R. Van den Broeck [et. al.], Leiden 1981, 495. Pogląd o platońskim 
Na rolę pitagoreizmu w kształtowaniu światopoglądu gnostyckiego zwrócił uwagę już Hipolit. Jego zdaniem filozofia ta (obok myśli platońskiej) wywarła zasadniczy wpływ na naukę walentynian ${ }^{12}$ oraz - jak pokazują to kolejne wypowiedzi autora Refutatio - na innych gnostyków ${ }^{13}$. O ile jednak w ogóle związki gnostycyzmu z platonizmem (a nawet stoicyzmem) zostały dość szczegółowo omówione, o tyle kwestia wpływów pitagorejskich na myśl (doktrynę) gnostycką (mimo, iż wskazuje się na nie) nie jest do tej pory należycie zbadana. Jednym z powodów tego stanu może być fakt, iż oryginalne teksty gnostyckie nie potwierdzaja, by ich autorzy odwoływali się bezpośrednio do myśli Pitagorasa i jego uczniów, która (i to jest kolejna przyczyna) przenikała do gnostycyzmu raczej za pośrednictwem literatury platońskiej ${ }^{14}$. Tym większe więc zainteresowanie może wzbudzić, znajdujący się w Marsanesie fragment 32, 12 - 33, 6, w którym autor przyjmuje nazewnictwo charakterystyczne dla pitagoreizmu, odwołując się do nauki o monadzie, diadzie oraz dziesięciu liczbach (konstytutywnych zasadach świata). Jednakże już w punkcie wyjścia powstają pytania: jak ma się zawarta $\mathrm{w}$ tym fragmencie myśl do prezentowanej przez autora platońskiej wizji rzeczywistości?, a ściślej, czy (i do jakiego stopnia) wizja owa mogła wpłynąć na rozumienie dwóch kluczowych terminów, użytych w interesującym nas fragmencie? Aby odpowiedzieć na te pytania, postaram się najpierw omówić te $\mathrm{z}$ ontologicznych założeń Marsanesa, które wynikają z przyjmowanych przez autora treści (średnio)platońskich, a następnie (na tym tle) odnieść się do wspomnianego wątku „pitagorejskiego”.

1. Platoński charakter ontologii i kosmogonii Marsanesa. Według Pearsona, w Marsanesie wpływy (średnio) platońskie widoczne są w trzech obszarach: w (1) ontologii, (2) doktrynie duszy (jej upadku i wstępowaniu) oraz (3) swoistego rodzaju monizmie charakteryzującym kosmogonię ${ }^{15}$. Nas interesuje tutaj przede wszystkim to, jaki wpływ na autora naszego utworu wywarła koncepcja rzeczywistości, znamionująca myśl platońską w wiekach od

charakterze Marsanesa podziela większość badaczy, natomiast pewne wątpliwości, co do platońskiego tła utworu, zgłasza J. Brancaer w artykule: Marsanes: un texte Séthien Platonisant?, „Le Muséon" 118 (2005) 21-41.

${ }^{12}$ Por. Hippolytus, Refutatio VI 21-29.

${ }^{13}$ Wpływ pitagoreizmu widoczny jest zwłaszcza w wykładzie gnostyka Monoimosa, który przyjmuje m.in. naukę o monadzie (utożsamiana jest z Człowiekiem: pierwszym bytem i źródłem wszechrzeczy, por. Hippolytus, Refutatio VIII 12,5) oraz dekadzie (obrazie monady, stanowiącej rozwiniecie pierwszych dziewięciu liczb, tworzących pierwsze zasady kosmogoniczne, zob. Hippolytus, Refutatio VIII 13, 1).

${ }^{14} \mathrm{Na}$ temat recepcji pitagoreizmu w literaturze platońskiej por. J.M. Rist, The Neoplatonic One and Plato's Parmenides, „Transactions and Proceedings of the American Philological Association” 93 (1962) 389-401; tenże, Neopythagoreanism and «Plato's» Second Letter, „Phronesis” 10 (1965) 78-81; C.A. Huffman, The „Pythagorean Precepts” of Aristoxenus: crucial evidence for Pythagorean moral philosophy, „The Classical Quarterly” NS 58 (2008) 104-119.

${ }^{15}$ Por. Pearson, Gnosticism as Platonism (I), s. 60. 
I przed Chr. do II po Chr. ${ }^{16}$, i jak ukształtowała ona jego naukę (wizję) na temat powstania świata. Aby odpowiedzieć na to pytanie, odwołajmy się zatem do nauki samym medioplatoników.

Historycy - badający myśl przedstawicieli filozofii medioplatońskiej zwracają uwagę, iż cechą charakterystyczną ontologii (i kosmologii) medioplatońskiej było zwrócenie uwagi na transcendencję Boga ${ }^{17}$. Myśl taką znajdujemy już u Plutarcha z Cheronei, który w traktacie O Izydzie $i$ Ozyrysie pisze:

„W rzeczywistości jest on [Ozyrys ${ }^{18}$ - A.Z.] niezmiernie oddalony od ziemi,

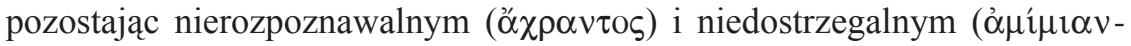

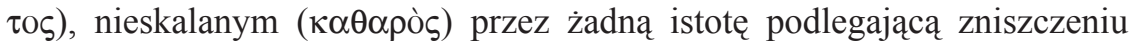
i śmierci”'19.

Cheronejczyk wskazuje tutaj na trzy podstawowe cechy Boga: nierozpoznawalność, niedostrzegalność i czystość. Ta ostatnia (której nie posiadają żadne istoty śmiertelne) świadczyć może o tym, że jest on wieczny i niezmienny, oraz bezcielesny. Na temat dwóch pierwszych przymiotów autor nasz wypowiada się w $O E$ delfickim. W dziełku tym analizuje naturę czasu, który sprawia, iż świat materialny zmienia się i umiera; w konkluzji autor stwierdza, iż tylko to, co jest poza czasem - czyli Bóg - jest niezmienny i wieczny:

„Ale bóg istnieje (jeśli trzeba to stwierdzić) i istnieje nie w żadnym czasie, ale w wiecznej nieruchomej, bezczasowej, nie znającej odchyleń, gdzie nic nie ma wpierw ani później, nic przyszłego, nic starszego ani młodszego"’20.

Z kolei Albinos przedstawia dowód na bezcielesny (duchowy) charakter Boga, jako argument podając jego niezmienność (przestrzenna, jakościowa, ontyczną - nie jest on bytem złożonym), z czego wynika, iż ,jest on bez ciała"21.

Filozofowie medioplatońscy wskazali zatem na wyraźną różnicę pomiędzy tym, co nie jest zrodzone, co jest wieczne, niezmienne, bezcielesne, a tym, co zrodzone, śmiertelne, zmienne, przypisując pierwszemu cechy substancji duchowej, drugiemu materialnej. Pogląd ten znalazł też swoje odbicie w charakterystycznym właśnie dla ontologii medioplatońskiej podziale na dwa światy: świat poznawalny umysłowo, zwany inteligibilnym lub

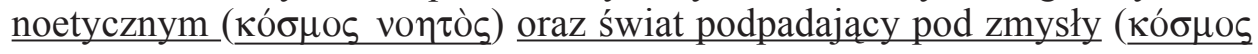

${ }^{16}$ G. Reale (Historia filozofii starożytnej, t. 4: Szkoty epoki cesarstwa, thum. E.I. Zieliński, Lublin 1999, 334-343) do przedstawicieli tego nurtu zalicza m.in. Eudorosa z Aleksandrii, Plutarcha, Gajosa, Albinosa i Apulejusza, którzy działali od 2. poł. I w. prz. Chr. do końca II w. po Chr.ystusie.

${ }^{17}$ Por. tamże, t. 4, s. 345-351.

${ }^{18}$ Ozyrys jest przedstawiony przez Plutarcha jako personifikacja Umysłu i Rozumu - zasady „najlepszych rzeczy”, por. Plutarchus, De Iside et Osiride, 371e.

${ }^{19}$ Por. Plutarchus, De Iside et Osiride 382f, thum. A. Pawlaczyk: Plutarch, O Izydzie i Ozyrysie, Poznań 2003, 89; por. też tekst grecki, tamże, s. 88.

${ }^{20}$ Plutarchus, De E apud Delphos 393a, thum. Z. Abramowiczówna: Plutarch, Moralia (Wybór), t. 2, BKF, Warszawa 1988, 28.

${ }^{21}$ Por. Albinus, Didascalicus X 7-8, cyt. za: Reale, Historia filozofii starożytnej, t. 4, s. 349. 
$\underline{\alpha i \sigma \theta \hat{\eta} \tau ం \varsigma})^{22}$. Odpowiednik pierwszego z nich odnajdujemy w platońskim Ti-

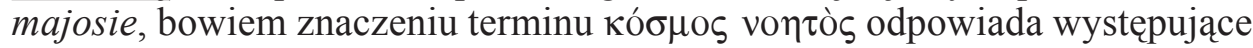

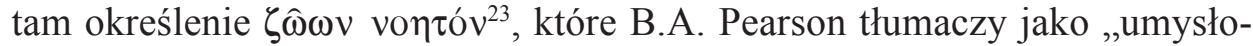
wy byt żyjący” (,intelligible living being”) ${ }^{24}$; oznacza ono wieczny, doskonały, niezrodzony pierwowzór wszechświata, który staje się wzorem świata utworzonego przez boga, nazywanego też ojcem i budowniczym oraz konstruktorem $^{25}$. Jednakże sam ten termin pojawia się dopiero u Filona Aleksandryjskiego ${ }^{26}$, który, jak dowodzi J.M. Dillon, w kwestii podziału światów głosił poglądy bliskie medioplatonikom ${ }^{27}$. Posłużył się nim m.in. w traktacie O stworzeniu świata, komentującego boskie dzieło kreacji, przedstawione w Księdze Rodzaju ${ }^{28}$ :

„Bóg mianowicie w swojej boskiej mądrości widział z góry, że piękne naśladownictwo nigdy nie może powstać bez pięknego modelu oraz że nie istnieje nic bez zarzutu wśród rzeczy postrzeganych zmysłami, co nie naśladuje prawzoru i umysłowej idei; i dlatego zanim chciał stworzyć ten świat widzialny,

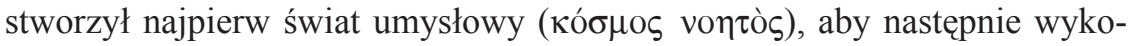
rzystać ten wzorzec niematerialny i podobny do Boga, stworzyć świat materialny, jako młode naśladownictwo starego wzoru"29.

Widzimy, iż Filon, podobnie jak Platon w Timajosie, uważa, iż nic nie może powstać bez pięknego, niematerialnego modelu, umysłowej idei, stanowiącej

${ }^{22}$ Według A.P. Bossa, na tym podziale opiera się dualizm nauki platońskiej i gnostyckiej; zob. tenże, ,Aristotelian” and ,Platonic” dualism in Hellenistic and Christian philosophy and Gnosticism, VigCh 56 (2002) 273-29; zob. też J.M. Dillon, Middle Platonists:80 B.C. to A.D. 220, New York 1996 (rev. ed. with a new afterward), 158-159; tenże, 'Asōmatos: nuance of incorporeality in Philo', w: Philon d'Alexandrie et le language de la philosophie, Turnhout 1998, 99-11; Reale, Historia filozofii starożtynej, t. 4, s. 351-356; J.R. Runia, A brief of the term ,kosmos noetos” from Plato to Plotinus, w: Traditions of Platonism. Essays in honour of J. Dillon, ed. J.J. Cleary, Aldershot 1999, 151-172.

${ }^{23}$ Por. Plato, Timaeus 37d; zob. też J.C. Van Winden, The world of ideas in Philo of Alexandria: an interpretation of „De opificio mundi” 24-25, VigCh 37 (1983) 210; Nag Hammadi Codices IX and $X$ (komentarz B.A. Pearsona, s. 258-259).

${ }^{24}$ Por. Pearson, jw.; w wydaniach polskich znajdujemy różne translacje: P. Siwek termin $\zeta \hat{\omega} o v$

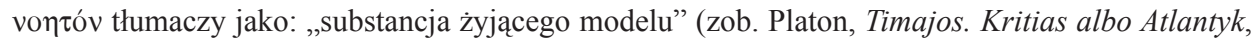
Warszawa 1986, 45), natomiast W. Witwicki całym zdaniem: ,pierwowzór jest istotą żywą” (zob. Platon, Timajos, Kritias, Warszawa 1960, 47).

${ }^{25}$ Por. m.in. Plato, Timaeus 29a-b; 37 c.

${ }^{26}$ Według B.A. Pearsona (Introduction, s. 244), nie wiadomo jednak, czy Filon faktycznie był jego autorem; por. R. Williamson, Jews in Hellenistic world: Philo, Cambridge 1989, 110-111; Dillon, Middle Platonists, s. 158-159.

${ }^{27}$ Por. Dillon, 'Asōmatos, s. 99-110.

${ }^{28}$ Por. Van Winden, The World of Ideas, s. 209.

${ }_{29}$ Philo Alexandrinus, De opificio mundi, 17, ed. R. Arnaldez, Les oeuvres de Philon d'Alexandrie, vol. 1, Paris 1961, 150, tłum. L. Joachimowicz, w: Filon Aleksandryjski, Pisma, t. 1, Warszawa 1986, 26. Filon posłużył się tym terminem również w swym dziele $O$ gigantach, używając go w tym samym znaczeniu, por. De gigantibus 61 . 
prawzór rzeczy materialnych (postrzeganych zmysłami). Ten idealny wzór Aleksandryjczyk nazywa właśnie światem umysłowym.

Podobne myśli odnajdujemy u Plutarcha, Apulejusza z Madaury, Albinosa i innych. Plutarch (tak jak Platon i Filon) stwierdza w traktacie O Izydzie i Ozyrysie, iż świat zmysłowy jest jedynie naśladowaniem bytu, którego jest obrazem poprzez przyjęcie przez materię formy (idei):

„Powstawanie jest bowiem w materii obrazem bytu, a to, co powstaje, jest naśladowaniem samego istnienia $"{ }^{30}$.

Natomiast Albinos, który starał się pogodzić poglądy Platona z nauką Arystotelesa, wyróżnił idee pierwsze (odpowiadają ideom platońskim) i idee drugie (odpowiadają im formy immanentne, które przyjął Arystoteles ${ }^{31}$ ), nazywając je ,niematerialnymi miernikami”. Filozof thumaczy bowiem:

„,...jeżeli materia jest ze swej natury bez miary, to trzeba, aby miarą dla niej było coś innego, lepszego i niematerialnego"32

Myśl tę w szerszym kontekście rozwija Madaurejczyk, który (wskazując na platońskie źródło swojego poglądu) wprost pisze o istnieniu dwóch rodzajów rzeczywistości. Pierwszą można poznać na drodze dociekań umysłowych; stanowi ona źródło (początek) wszystkiego Jest ona niezmienna, tożsama ze sobą, i tylko ona jest bytem prawdziwym. Drugą (rzeczywistość) stanowi świat materialny, który powstaje w czasie, a także zmienia się i przekształca:

„Według Platona, istnieją dwie rzeczywistości - my nazywamy je istotami [= substancjami] $-\mathrm{z}$ których biorą początek wszystkie rzeczy i sam świat: pierwsza jest ujmowana jedynie myślą, druga może podpadać pod zmysły. Ale pierwsza, która jest ujmowana oczyma umysłu, znajduje się zawsze w tym samym stanie, jest równa i podobna do siebie, jako ta, która naprawdę jest; druga natomiast, która - jak twierdzi Platon - rodzi się i umiera, jest ujmowana przez zmysłowe i nierozumne mniemanie. I o ile pierwsza jest uznawana za byt prawdziwy, o tyle druga nie jest prawdziwym bytem. Pierwszą substancją czy też istotą jest pierwszy bóg i umysł, i formy rzeczy, i dusza; drugą substancją jest to wszystko, co otrzymuje formę, co rodzi się i bierze początek od modelu substancji wyższej, co może się zmienić i przekształcać, uciekając i rozpraszając się jak woda rzek" ${ }^{33}$.

Zauważmy, iż świat duchowy, opisywany przez Madaurejczyka w De Platone, jest zróżnicowany i ułożony hierarchicznie. Wymieniając poszczególne

${ }^{30}$ Plutarchus, De Iside et Osiride, 372f-373a, thum. A.Pawlaczyk, s. 67; por. tekst grecki, tamże, s. 66.

${ }^{31}$ Por. Reale, Historia filozofii starożytnej, t. 4, s. 351-355.

${ }^{32}$ Albinus, Didascalicus IX 3, cyt. za: Reale, Historia filozofii starożytnej, t. 4, s. 353.

${ }^{33}$ Apuleius, De Platone I 193, cyt. za: Reale, Historia filozofii starożytnej, t. 4, s. 349-350; por. tekst łac. w: L. Apuleii opera omnia, pars 2, instruxit G.F. Hildebrand, Lipsiae 1842, 185. 
jego szczeble Apulejusz pisze:

„Et primae quidem substantiae vel essentiae deum primum et materiam formasque rerum et animam" 34 .

G. Reale w swoim przekładzie dodał jeszcze do tej listy umysł, umieszczając go przed formami rzeczy, czyli ideami ${ }^{35}$. Owa korekta nie jest przypadkowa, świadczy bowiem, jak pokazuje to uczony, o wspólnej wielu średnim platonikom tendencji, jaką było ,umieszczenie nous (umysłu albo intelektu) ponad psyche (duszą)"36; to z kolei prowadziło, zdaniem włoskiego uczonego, „ku nauce, która zapowiadała plotyńskie hipostazy. Więcej nawet, wiele tekstów filozofów medioplatońskich, jeśli się je czyta pod pewnym kątem, zdaje się wręcz zawierać, przynajmniej w zalążku, wszystkie trzy plotyńskie hipostazy, którym są Jedno, Umysł i Dusza" ${ }^{37}$. Zapowiedź takiej triady widzimy wyraźnie w cytowanej wyżej wypowiedzi Apulejusza. Można ją też odnaleźć u Plutarcha i Albinosa ${ }^{38}$.

Pozostaje jeszcze kwestia miejsca, jakie w tym systemie zajmują (tworzące kosmos noetos) idee oraz ich relacji do Boga. Madaurejczyk prawdopodobnie umieszczał je po intelekcie, wskazując tym samym na ich zależność od Nous. Zagadnienie to rozpatrywał wcześniej również Filon, który (w przeciwieństwie do Platona i starszych platoników, umieszczających świat idei ponad Demiurgiem) nie tylko wskazał na nadrzędność Boga-sprawcy w stosunku do świata noetycznego, ale nadto - co podkreślają m. in. Van Winden i Williamson - świat ten umieścił w (Umyśle Boga) - Logosie ${ }^{39}$ (w którym niektórzy badacze widzą antycypację drugiej osoby Boskiej ${ }^{40}$ ). Jeszcze wyraźniej kwestię relacji zachodzącej pomiędzy Umysłem i światem umysłowym (ideami) sformułował Albinos, który przedstawiając je jako myśli Pierwszego Intelektu, na tej podstawie dowodził też ich istnienia:

„załóżmy, że Bóg jest intelektem lub czymś myślącym i posiada myśli, a te myśli są wieczne i niezmienne; jeśli jednak rzeczy tak się maja, to idee istnieją"

${ }^{34}$ Tamże, inst. G.F. Hildebrand, s. 185.

${ }^{35}$ Por. tamże, inst. G. F. Hildebrand, s. 185: „Ideas vero, id est formas omnium”.

${ }^{36}$ Por. Reale, Historia filozofii starożytnej, t. 4, s. 355.

${ }^{37}$ Por. jw.

${ }^{38}$ Por. Albinus, Didascalicus X 2, cyt. za: Reale, Historia filozofii starozytnej, t. 4, s. 356: „Intelekt jest lepszy od duszy, a od intelektu w możności lepszy jest ten, który aktualnie myśli wszystkie rzeczy razem i zawsze, a jeszcze bardziej doskonała od niego jest jego przyczyna i to, co może być ponad nimi; taki jest Bóg".

${ }^{39}$ Por. Van Winden, The world of ideas, s. $217 \mathrm{nn}$; R. Williamson, Jews in Hellenistic world, s. 111; według M. Osmańskiego (Filon z Aleksandrii, PEF III 445) świat umysłowy jest utożsamiony z Logosem.

${ }^{40}$ Por. Osmański, Filon z Aleksandrii, PEF III 445.

${ }^{41}$ Albinus, Didascalicus IX 3, cyt. za Reale, Historia filozofii starożytnej, t. 4, s. 353. 
A. Pearson zauważa, iż związki Marsanesa z doktryną medioplatońską najwyraźniej widać w rozdz. 2,12-4,24 ${ }^{42}$. Tym, co różni utwór od (cytowanych) pism platońskich, to przede wszystkim (o czym wspomniano we wstępie) profetyczny charakter. Autor wiedzę swoją otrzymuje bowiem od Objawiciela, który odsłania ją stopniowo, łamiąc kolejno trzynaście pieczęci

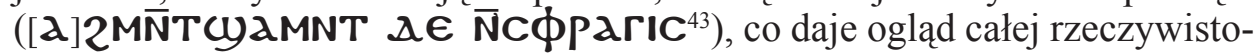
ści, która - jak się okazuje - ma strukturę gradualną. Na samym dole (pieczęć

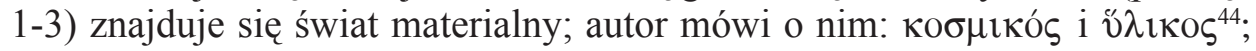
należą do niej wszystkie istoty posiadające ciało $(\sigma \hat{\omega} \mu \alpha)$. Ponad nim (pieczęć 4-5) jest - jak zauważa Pearson - sfera wygnania duszy i jej transmigracji ${ }^{45}$. Na kolejnym szczeblu (pieczęć 6) tej drabiny znajdują się byty, które są bezcielesne $\mathrm{i}$ istnieją indywidualnie ${ }^{46}$. Nad nimi jest sfera intelektu wraz z całym światem umysłowym (KOCMOC NOHTOC), która zostaje odsłonięta po złamaniu siódmej pieczęci:

„Zaś ósma [A. Z. pieczęć]/ dotyczy Umysłu, który jest/ męski, który wystapił/ na początku, i dotyczy substancji (OYCIa)/ która jest bezcielesna (T€ MN̄TEC CCUMA) [wraz] z umysłowym światem (KOCMOC NOHTOC) ${ }^{m 47}$.

Użyte tutaj terminy NOYC i KOCMOC NOHTOC, najdobitniej świadczą o wpływach platońskich. Autor wraca jeszcze kilkakrotnie do kwestii umysłu/ intelektu oraz świata umysłowego (idealnego) ${ }^{48}$; porównuje go też ze światem zmysłowym. Wreszcie na kolejnych szczeblach (pieczęć 10 oraz 11-12) autor umieszcza Dziewicę Barbelo (Ba PBH $\boldsymbol{\lambda} \boldsymbol{C W})^{49}$ - w innych miejscach określana jest jako „Męska Dziewica”, zaś w innych tekstach setiańskich, np. w Ewangelii Egipcjan, nazywana jest Matką) - i Niewidzialnego ([a20]Pa TOC), określonego też Trójsilnym lub posiadającym trzy siły - ([OY]NT€q Cy[a]

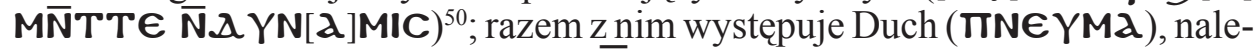

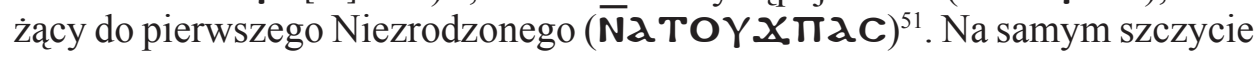

${ }^{42}$ Por. Pearson, Gnosticism as Platonism (I), s. 60.

${ }^{43}$ Marsanes X 2, 12-13, ed. B.A. Pearson, s. 252.

${ }^{44}$ Por. Marsanes X 2, 16-19; Pearson zauważa, iż występujący w tym fragmencie termin

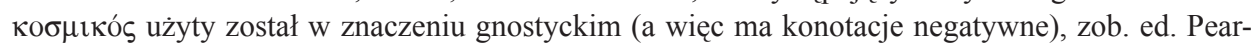
son, s. 255 (komentarz).

${ }^{45}$ Por. Marsanes X 2, 26 - 3, 17; por. Zostrianos 5, 24-27; zob. też B.A. Pearson, Gnosticism as Platonism (I), s. 61.

${ }^{46}$ Por. Marsanes X 3, 18-25.

${ }^{47}$ Marsanes X 1: 4, 2-7, ed. B.A. Pearson, s. 258: TMA2CUMOY/[N€] $\boldsymbol{\lambda} \in \mathbf{E T B \epsilon}$

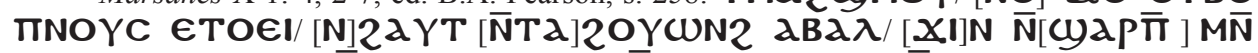
TOYCIa Є/ [TE MNTTEC C]CUMA MÑ TKÖC/ [MOC N̄NOH]TOC.

${ }^{48}$ Por. Marsanes X 1, 4: 6-7; 5,18-19. 22. 24-25; 34*,20; 41*,2-6.

${ }^{49}$ Por. Marsanes X 4, 10-12.

${ }^{50}$ Por. Marsanes X 4, 15-16.

${ }^{51}$ Por. Marsanes X 4, 19. 
(pieczęć 13) znajduje się Bóg, który jest poza wszelkim bytem (a TOYCIa,

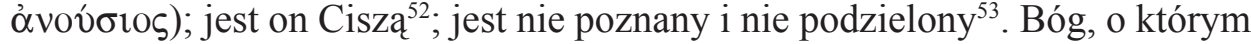
pisali medioplatończycy, aczkolwiek transcendentny wobec świata i bardzo daleki, nigdy nie był jednak aż tak odległy, jak u gnostyków. Pearson dostrzega w nim nawet antycypację plotyńskiego Jedna/ Jednego - Boga, który „,nie

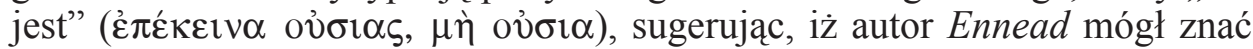
koncepcję gnostycką ${ }^{54}$.

Zauważyć można, iż ontyczną podstawą opisanej przez autora hierarchicznie ułożonej rzeczywistości, są dwa rodzaje substancji: materialna oraz duchowa - samo zrodzona (ג YTOR EN[NHT]OC) i bezcielesna (MN̄TEC CCUMa; aCCUMATON; $\alpha \sigma \omega \mu \alpha \tau o v)^{55}$. Można domniemywać, iż zgodnie z zasadami ontologii platońskiej, pierwsza przekształca się, zmienia i ginie, druga nie zmienia się i jest nieśmiertelna. Jednakże świat duchowy przedstawiony przez autora Marsanesa jest bardziej skomplikowany. Należą do niej (wyłączając bezimiennego Boga): Niewidzialny/ Trójsilny, Barbelo, Umysł wraz ze światem umysłowym, wreszcie Dusza. Wydaje się, iż trzy pierwsze hipostazy odpowiadać mogą setiańskiej triadzie: Ojciec-Matka-Syn, jaka pojawia się w Ewangelii Egipcjan ${ }^{56}$. Ku takiej właśnie interpretacji skłania się Pearson, który w oparciu o tekst Apokryfu Jana rozwija ją następująco: Ojciec/ Monada/ Niewidzialny Duch ${ }^{57}$ - Matka/ Barbelo/ Ennoia ${ }^{58}$ - Syn/ Monogenes/ Umysł/ Autogenes ${ }^{59}$. Odmienność tej koncepcji polega na tym, że Umysł stanowi tutaj ostatnie ogniwo triady, a nie - tak jak u medioplatoników - drugie.

Przy uważnej lekturze pierwszych czterech rozdziałów Marsanesa można zaryzykować twierdzenie, iż autor pisma sprowadza całą rzeczywistość do czterech poziomów bytowania, w czym bardzo wyraźnie można również zauważyć inspiracje platońskie. Są to: (1) Bóg, (2) Intelekt wraz z ideami, (3) Dusza i (4) ciała materialne ${ }^{60}$. Możliwy jest też inny podział: (1) sfera Ducha (Bóg/ Jedno i Barbelo), (2) sfera Umysłu (Logos/Syn) i rzeczy umysłowych, (3) sfera Duszy (Psyche) i (4) sfera cielesna; w tym kontekście dwie pierwsze sfery odpowiadałyby setiańskiej triadzie.

W tym kontekście powraca pytanie o stosunek świata materialnego do świata idealnego. Autorzy platońscy piszą najczęściej o naśladowaniu lub

${ }^{52}$ Por. Marsanes X 4, 19-23.

${ }^{53}$ Marsanes X 1: 4, 21-24, ed. B.A. Pearson, s. 260, thum. własne: „[Cisza], która nie była poznana, a początek jej nie był podzielony".

${ }^{54}$ Por. Pearson, Gnosticism as Platonism (I), s. 63.

${ }^{55}$ Por. Marsanes X 3, 19-20; 4, 6

${ }^{56}$ Por. B.A. Pearson, Introduction, s. 241-242; por też jego komentarz do Marsanesa, s. 260.

${ }^{57}$ Por. Apocryphon Iohannis II 2, 25 - 4, 26.

${ }^{58}$ Por. tamże II 4, 26 - 6, 10.

${ }^{59}$ Por. tamże II 6, 10 - 7, 30.

${ }^{60}$ B.A. Pearson proponuje inny nieco podział (Gnosticism as Platonism (I), s. 63), z którym jednakże trudno się zgodzić, a jest to: (1) Nie istniejący - poziom 12-13, (2) Barbelo - poziom 8-10, (3) Dusza - poziom 4-6. 
odwzorowaniu, co podnosi wartość tego pierwszego. Podobnie czyni nasz autor, który nie tylko nie potępia go, ale pisze o jego ocaleniu; m.in. wypowiedź ta stała się dla Pearsona podstawą do stwierdzenia, iż kosmogonia Marsanesa ma charakter monistyczny ${ }^{61}$ :

„Poznawałem część po części całe miejsce bezcielesnej substancji (OYCla;

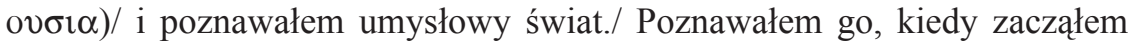
rozważać,/ że pod każdym względem poznawalny zmysłowo/ świat/ jest wart / by być ocalonym w całości. "

Poznawanie, o jakim pisze autor, jest przechodzeniem od jedności do wielości i odwrotnie. Każdy byt wyższy stanowi bowiem uzasadnienie dla bytu znajdującego się na niższym szczeblu, z kolei jego istnienie wymaga zwrócenia się ku rzeczywistości wyższej. Aby lepiej zilustrować ten rodzaj zależności, odwołajmy się do słów G. Reale, który streszczając wywody Platona, przedstawione w Fedonie, tak pisze: ,Jak sfera wielości rzeczy postrzeganych zmysłami zależy od sfery idei, tak sfera wielości idei zależy od następnej sfery rzeczywistości, z której wywodzą się idee; ona dopiero jest sferą najwyższą i pierwszą w sensie absolutnym. Sferę tę stanowią pierwsze zasady (są nimi Jedno i nieokreślona Diada" ${ }^{33}$.

2. Wypowiedź o monadzie, diadzie i liczbach (Marsanes 32, 12-33, 6). W świetle powyższych wywodów interesująca wydaje się wypowiedź, którą znajdujemy w rozdz. 32,12-33,6. Autor nawiązuje w niej wyraźnie do nauki pitagorejczyków o monadzie i diadzie, jako najwyższych (pierwszych) zasadach oraz o dziesięciu emanujących z nich liczbach. Pisze mianowicie tak:

„Diada/ i monada/ nie są podobne do niczego, ale/ one są pierwsze w istnieniu./ Diada, będąc podzielona/ została podzielona z monady i/ przynależy do hipostazy./ Zaś triada otrzymała elementy/. A pentada/ otrzymała zgodę (harmonię),/ heksada była doskonała sama z siebie./ Hebdomada otrzymała piękno"64

Kolejny fragment $(32,25$ - 33, 6nn) posiada liczne luki. Autor wymienia tutaj kolejne liczby, aż do dwunastki. Na podstawie zachowanych słów (bądź ich części) można się jedynie domyślać, iż z ogdoadą związana jest „gotowość”

${ }^{61}$ Por. Pearson, Gnosticism as Platonism (I), s. 69-72.

${ }^{62}$ Marsanes X 5, 19-21, ed. B.A. Pearson, s. 260-262: a2ICג YNE Kג T[ג] MEPOC

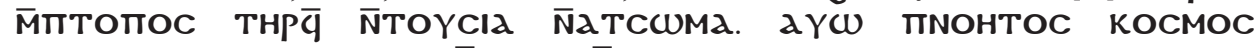

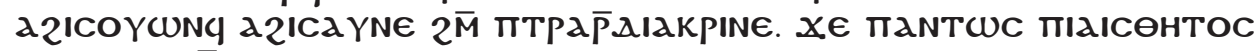

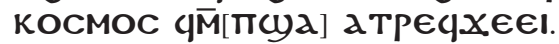

${ }^{63}$ G. Reale, Historia filozofii starożytnej, t. 2: Platon i Arystoteles, Lublin 2001, 115.

${ }^{64}$ Marsanes X 32, 12-24, ed. B.A. Pearson, s. 308-310: T $\boldsymbol{\lambda} Y[\mathbf{\lambda C}] \boldsymbol{\lambda} \in \mathbf{M} \overline{\mathbf{N}}$ TMONaC

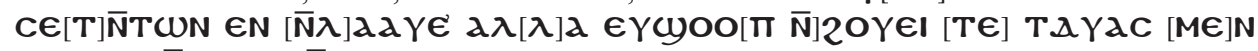

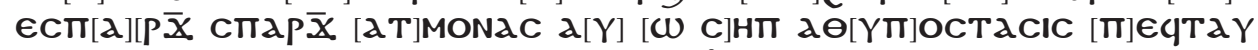

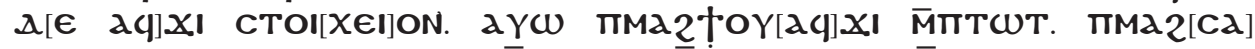

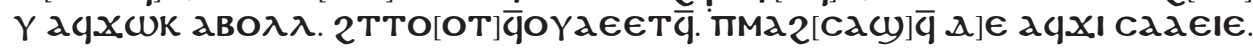


(do działania?), zaś z nonadą „,wielkość” (ilość?). O dekadzie (dwuwiersz ten został zachowany w całości) pisze: „otrzymała wszystkie miejsca" ${ }^{\prime 6}$.

Zastanówmy się teraz, z jakich źródeł korzystać mógł nasz autor, pisząc o monadzie i diadzie. Czy naukę o nich mógł przyjąć za pośrednictwem platoników, czy też korzystał raczej z pism pitagorejczyków, a jeśli tak, to z jakich? Dlaczego włączył on ich naukę o dwóch pryncypiach do swojego kosmogonicznego wywodu?

Spróbujmy odpowiedzieć najpierw na pierwsze pytanie. Według źródeł doksograficznych termin monada pochodził od Pitagorasa ${ }^{66}$. Sprawą dyskusyjną pozostaje jednak to, czy faktycznie mógł on używać tego terminu. C.J. De Vogel uważa, iż pojawił się on w literaturze filozoficznej po Platonie ${ }^{67}$. Istotnym argumentem za jego postplatońskim pochodzeniem jest fakt, iż sam Platon, który korzystał z nauk pitagorejczyków i pisał o Jednym (๕̌v) oraz Diadzie

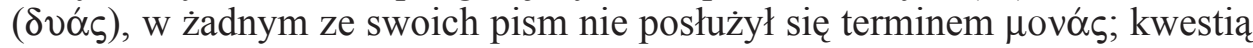
otwarta pozostaje, czy znał samo pojecie ${ }^{68}$. De Vogel twierdzi, iż określenie „monada” pojawiło się dopiero u Filolaosa, który nadto przyjął, iż jest ona początkiem wszystkiego ${ }^{69}$. Jednakże dopiero u neopitagorejczyków pojawia się pogląd, iż monada i diada stanowią dwie zasady wszystkiego. Neopitagorejskie pochodzenie tego poglądu poświadczają doksografowie. Według cytowanego przez Diogenesa Laertiosa Aleksandra Polihistora, pitagorejczycy uważali, że:

„Początkiem wszechrzeczy jest jednostka, czyli monada ( $\mu$ ovós). Z monady

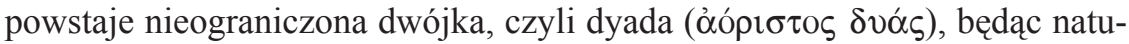
ralnym podłożem dla jednostek, swej przyczyny. Z monady i nieograniczonej dyady powstają liczby"

O tym, iż (neo)pitagorejczycy widzieli w monadzie i diadzie podstawowe pryncypia świadczą też wypowiedzi Aetiosa ${ }^{71}$ i Sekstusa Empiryka, który przypisując (zgodnie z tendencją doksograficzną) pogląd ten Pitagorasowi pisze:

„Najwyższymi zasadami wszystkich rzeczy są: pierwsza Monada i nieokreślona Diada [...]. Spośród tych zasad Monada pełni funkcję przyczyny spraw-

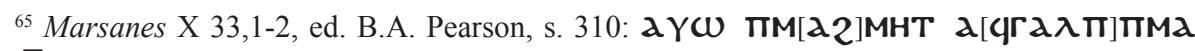

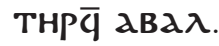

${ }^{66}$ Por. Reale, Historia filozofii starożytnej, t. 4, s. 390-394.

${ }^{67}$ Por. C.J. de Vogel, Pythagor and Early Pythagoreanism, Assen 1966, 207; P. Świercz, Jedność $w$ wielości. Świat, czlowiek, państwo w refleksji nurtu orficko-pitagorejskiego, Katowice 2008, 224.

${ }^{68}$.Por. Plato, Phaedo 101c; Parmenides 149c.

${ }^{69}$ Por. P. Świercz, Jedność w wielości, s. 224.

${ }^{70}$ Diogenes Laertios, Vitae philolosophorum VIII 25, tłum. B. Kupis: Diogenes Laertios, Żywoty filozofów, tłum. B. Kupis [et al.], BKF, Warszawa 1968, 482.

${ }^{71}$ Por. Placita I 3, 8. 
czej, a Diada - funkcję biernej materi, i jak z nich wzięły początek liczby, tak samo one wytworzyły wszechświat i wszystkie rzeczy"72.

Trudno jest niestety rozstrzygnąć, czy pitagorejczycy wyprowadzali diadę z monady, czy też istniała ona, tak jak monada, jako odwieczna najwyższa zasada sprawcza. Funkcjonować mogły obie wersje. Wypowiedź Aleksandra zdaje się bowiem potwierdzać pierwsze stanowisko - Sekstusa Empiryka drugie. Uznanie przez naszego autora monady i diady za pierwsze zasady, świadczyłoby zatem o tym, iż znał on literaturę neopitagorejską i czerpał z niej. Nadto, podobnie jak jej autorzy, łączył (jak się wydaje) monadę ze sferą noetyczną.

Interesujący wydaje się nadto fakt uznania hipostatycznej formy monady i diady; wskazuje na to wiersz 32,15. Również i taki pogląd pojawił się już wcześniej u neopitagorejczyków. Jej autorem jest Numenios z Apamei, który zsyntetyzował myśl piagorejską z platońska; przyjął bowiem naukę o monadzie, którą utożsamił z bogiem i nadał postać hipostazy, oraz o diadzie, jak też pogląd o istnieniu trzech bogów, z których dwóch kolejnych naśladuje swojego poprzednika. G. Reale twierdzi, że gdyby odróżnił on Jedno od monady, co jest bardzo prawdopodobne, to: „w takim wypadku nauka o zasadach mogłaby współgrać z jego teologią trzech bogów. Pierwszy Bóg, czyli Dobro samo w sobie, byłby Jednym (i tak faktycznie został nazwany). Monada byłaby drugim bogiem i wywodziłaby się $\mathrm{z}$ naśladowania Jednego [...]. Trzeci zaś bóg powstałby w sposób opisany wyżej, to znaczy poprzez kontakt Monady z Diadą".

Wydaje się, że również i tę myśl odczytać można z tekstu Marsanesa. Znajdujemy bowiem podstawy, by Niewidzialnego boga skojarzyć z Jednym, a Umysł z monadą, choć kwestią dość problematyczną pozostaje przyporządkowanie Diady określonej sferze bytowej lub hipostazie. Konsekwentnie idee, które znajdują się w Umyśle, można by identyfikować z liczbami, z których wzięły swój początek wszystkie rzeczy.

Pozostaje jeszcze jedna kwestia: jak autor Marsanesa rozumie liczby? $\mathrm{Z}$ zachowanego fragmentarycznie cytatu widzimy, iż przyporządkowane są im różne właściwości (cechy): triada (trójka) odpowiada tutaj elementom. Przypomnijmy, iż u Platona były to bryły (czyli liczby sześcienne): czworościan stanowił podstawowy element ognia, sześcian ziemi, ośmiościan powietrza, a dwunastościan wody. Z piątką nasz gnostyk łączy harmonię, z szóstką doskonałość, z siódemką piękno, z ósemką gotowość (do działania), z dziewiątką - wielkość (lub ilość). Dziesiątka, która „łączy wszystkie miejsca”, jest najdoskonalsza, zawiera bowiem w sobie cechy wszystkich pozostałych. Stanowią one doskonałe wzorce, czyli - używając słów Albinosa - „mierniki” ciał. Ale nie są one ich budulcem w sensie materialnym (tak jak przedstawiali to starsi pitagorejczycy). Czy wobec tego można obronić tezę Pearsona

${ }^{72}$ Sextus Empiricus, Adversus mathematicos X 277, cyt. za: Reale, Historia filozofii starożytnej, t. 4. s. 412 . 
o monistycznym charakterze świata, nawet jeśli będziemy mówili tylko o monizmie duchowym (czy umysłowym)? Pytanie to pozostaje otwarte.

Na zakończenie warto raz jeszcze podkreślić, iż w Marsanesie, zwłaszcza w tych fragmentach, które dotyczą kosmogonii, znajdujemy bardzo ciekawą syntezę, której źródłem są: ontologia (i kosmologia) neopitagorejska oraz medioplatońska.

\section{THE PLATONIST MARSANES AND ITS PYTHAGOREAN THEME}

\section{(Summary)}

The opening part of this paper presents the influences of Middle-Platonist philosophy discernible in the ontology presupposed in the Marsanes. These are particularly conspicuous in the hierarchical arrangement of reality. At the summit of the Universe there is Invisible God, second in the hierarchy comes Barbelo, the Mind, complete with the world of intellect (identified with Platonic ideas), then follows the Soul and the world of the sense perception, which is the reflection of ideas. The second part contains a discussion of the fragment NHC X 32, 12 - 33, 6 . described in the literature as „Pythagorean”. The fragment contains reference to the two eternal principles: monas and dyas, as well as to the ten cosmogonical principles. In this context the question arises as to the relationship of the cosmogony assumed in this fragment and the one presupposed by the author of the MiddlePlatonist exposition. Finally, it is concluded, that the Marsanes cosmogony is typical of its period in being a synthesis comprising themes drawn from ontology (and cosmology) of both: Neopythagoreanism and Middle-Platonism. 
